DOI: 10.32703/2415-7422-2021-11-1-125-149

\title{
Artemii Bernatskyi
}

UDC 621.373.826: 681.7.069.24

E. O. Paton Electric Welding Institute of the National Academy of Sciences of Ukraine

11 Kazymyr Malevych Street, Kyiv, Ukraine, 03150

e-mail: Bernatskyi@paton.kiev.ua

https://orcid.org/0000-0002-8050-5580

\section{Vladyslav Khaskin}

Guangdong Welding Institute (China-Ukraine E. O. Paton Institute of Welding) 363 Changxing Road, Tian He, Guangzhou City, China, 510650

e-mail: Khaskin@ua.fm

http://orcid.org/0000-0003-3072-6761

\section{The history of the creation of lasers and analysis of the impact of their application in the material processing on the development of certain industries}

Abstract. The paper is devoted to the analysis of the history of the creation of the laser as one of the greatest technical inventions of the 20th century. This paper focuses on establishing a relation between the periodization of the stages of creation and implementation of certain types of lasers, with their influence on the invention of certain types of equipment and industrial technologies for processing the materials, the development of certain branches of the economy, and scientific-technological progress as a whole. In preparing the paper, the generally accepted methods, which are widely used in the preparation of historical research works, have been applied: the historical method-for the study and interpretation of the texts of primary sources and the search for other evidence used for research, as well as for the presentation of historical events associated with the development of laser technology; the historicalgenetic method - for studying the genesis of specific historical phenomena and analyzing the causality of changes in the development of laser technology; the historical-critical method - for displaying cause-and-effect relationships, reconstructing events that influenced the development of laser technology; the method of historical periodization. The variety of different possible options for the use of lasers did not allow placing all the collected materials within the framework of one paper, and therefore, the authors have decided to dwell on the facts, which, in the opinion of the paper's authors, are the most interesting, significant, poorly studied, and little known. The paper discusses the stages of: invention of the first laser; creation of the first commercial lasers; development of the first applications of lasers in industrial technologies for processing the materials. Special attention is paid to the "patent 
wars" that accompanied different stages of the creation of lasers. A comparative analysis of the market development for laser technology from the stage of creation to the present has been carried out. It has been shown that the modern market for laser technology continues to develop actively, as evidenced by the continued stable growth of laser sales over the past 10 years. This indicates that the demand for laser technology is inextricably linked with the development of high technology production and scientific-technological progress. The analysis has shown that recently, the trends in the use of laser technology have changed; in particular, their industrial and medical applications are decreasing, while there is an increase in their use in the fields of sensor production and communication.

Keywords: laser; history of lasers; Theodore Maiman; National Museum of American History; laser market; laser applications

\section{Introduction.}

The 20th century was rich in great inventions, one of which, undoubtedly, was the laser. At the same time, a laser is just a device or a so-called "tool" whereby it became possible to carry out various actions, which ultimately led to the desired result. The creation of some types of lasers has contributed to the invention of not only new types of apparatuses, devices, but also the emergence of new technological processes and even entire branches of science and industry (Belforte, 2010; Hecht, 2010; Hess, 2013; Ion, 2005; Rigby, 2010). This paper is devoted to this direction, namely, the analysis of the influence of the invention and the stages of the subsequent introduction of certain types of lasers on the stages of development of certain processes, types of technology and industries.

The purpose of the paper is to establish a relation between the periodization of the stages of creation and implementation of certain types of lasers, with their influence on the invention of certain types of equipment and technologies, the development of certain branches of the economy, and scientific-technological progress as a whole.

\section{Research methods.}

The authors of this paper have many years of experience in operating various types of lasers, which they acquired by developing various technologies for laser processing of materials (Bernatskyi, Berdnikova, Klochkov, Sydorets, \& Chinakhov, 2019; Bernatskyi, Sydorets, Berdnikova, Krivtsun, \& Chinakhov, 2020; Khaskin, Bernatskyi, Siora, \& Nikulin, 2011; Markashova, Berdnikova, Bernatskyi, Sydorets, \& Bushma, 2019; Shelyagin et al., 2005a; Shelyagin et al., 2005b; Shelyagin et al., 2018; Siora \& Bernatskyi, 2011). Interest in the history of the stages of creation and implementation of certain types of lasers was the impetus for writing this work. In preparing the paper, the generally accepted methods, which are widely used in the preparation of historical research works, have been applied (Choudhury Kaul, Sandhu \& Alam, 2019; Storozum et al., 2019; Strelko et al., 2019a; Strelko et al., 2019b; Van Lent \& Durepos, 2019; Zhang \& Liu, 2019): the historical method - for 
the study and interpretation of the texts of primary sources and the search for other evidence used for research, as well as for the presentation of historical events associated with the development of laser technology; the historical-genetic method for studying the genesis of specific historical phenomena and analyzing the causality of changes in the development of laser technology; the historical-critical method - for displaying cause-and-effect relationships, reconstructing events that influenced the development of laser technology; the method of historical periodization. The variety of different possible options for the use of lasers did not allow placing all the collected materials within the framework of one paper, and therefore, the authors have decided to dwell on the facts, which, in the opinion of the paper's authors, are the most interesting, significant, poorly studied, and little known.

\section{Results and discussion.}

The beginning. First generation of laser radiation. Press conference by Theodore Maiman. Finding the first laser applications.

It is a well-known fact that the first generation of laser radiation on a ruby crystal was obtained on May 16, 1960, by Theodore Harold Maiman, who was then at Hughes Research Laboratories, the research arm of the Hughes Aircraft Company (Figure 1). However, the facts that preceded and took place immediately after this event are little known.

Above all, while fighting to fund his research, Theodore Maiman faced serious competition for the primacy of his discovery (Rigby, 2010). When he submitted his paper to Physical Review Letters, it was rejected as "just another maser paper". Maiman quickly wrote a shorter 300-word version of his paper and submitted it to Nature, where it was accepted (Maiman, 1960). As a scholar, Maiman wanted to publish his paper first, but Hughes Labs executives were nervous as the Bell Labs team could be very close to a similar result. Therefore, before Maiman's Nature paper was published, Hughes Labs decided to hold a press conference that was scheduled for July 7, 1960. The photographer hired to shoot the first laser was not impressed - it was too small (see Figure 1.a).

After inspecting the lab, the photographer picked up a later prototype with a medium-sized flashtube and a $5 \mathrm{~cm}$ long ruby rod (Figure 2) (Rigby, 2010). The photographer told Maiman, "Hold this in front of your face and I know this will be picked up by every news outlet, but if we print this, this first laser, it won't go anywhere". The photographer was right. The day after the press conference, all major newspapers published this photo. The headlines of papers about the laser invention were calculated to be a big sensation, for example, the Los Angeles Herald published an article with the headline "L.A. man discovers science-fiction death ray", and Newsweek published an article with the headline "This might very well be the of the death ray". 


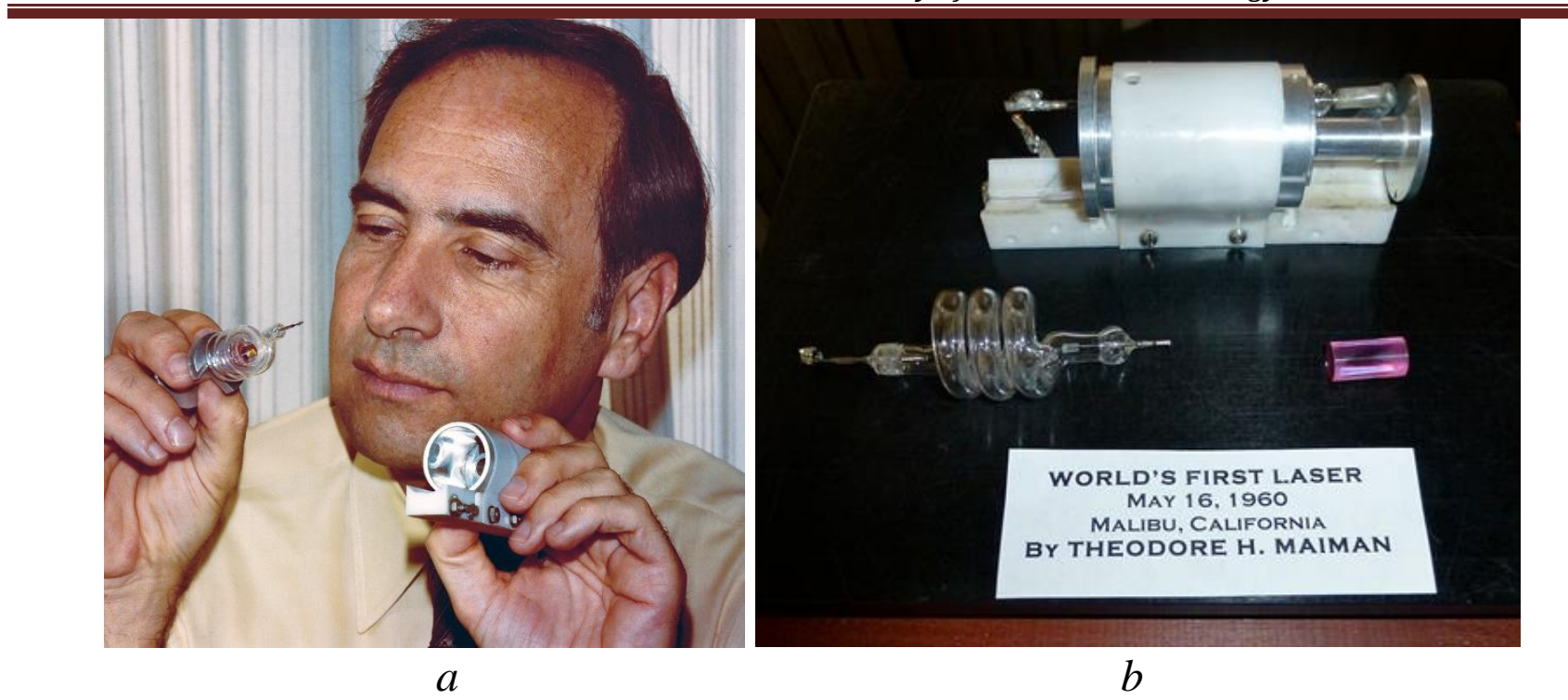

Figure 1. Theodore Maiman (a) (Rigby, 2010) with the first laser prototype ( $b$ ) (Theodore Maiman - Wikipedia).

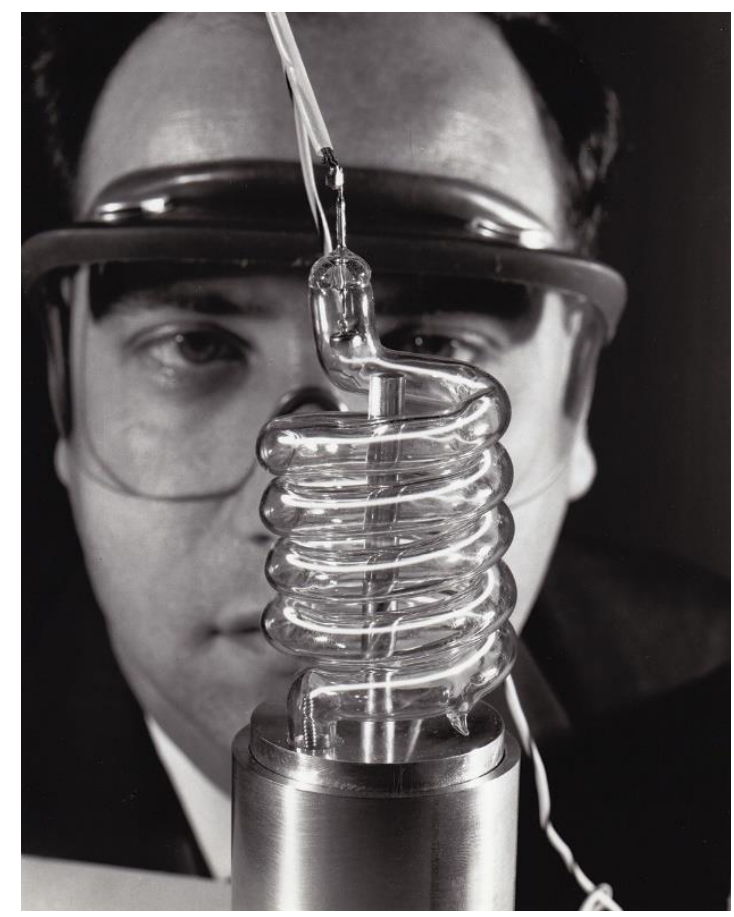

Figure 2. The photograph issued at the 7 July 1960 Hughes press conference showing Maiman with a later prototype laser - not the first one (Rigby, 2010).

The further fate of the first sample of the ruby laser created by Theodore Maiman is interesting. The National Museum of American History has photographs of one of the possible versions of Theodore Maiman's first ruby laser (Figure 3) (National Museum of American History). 


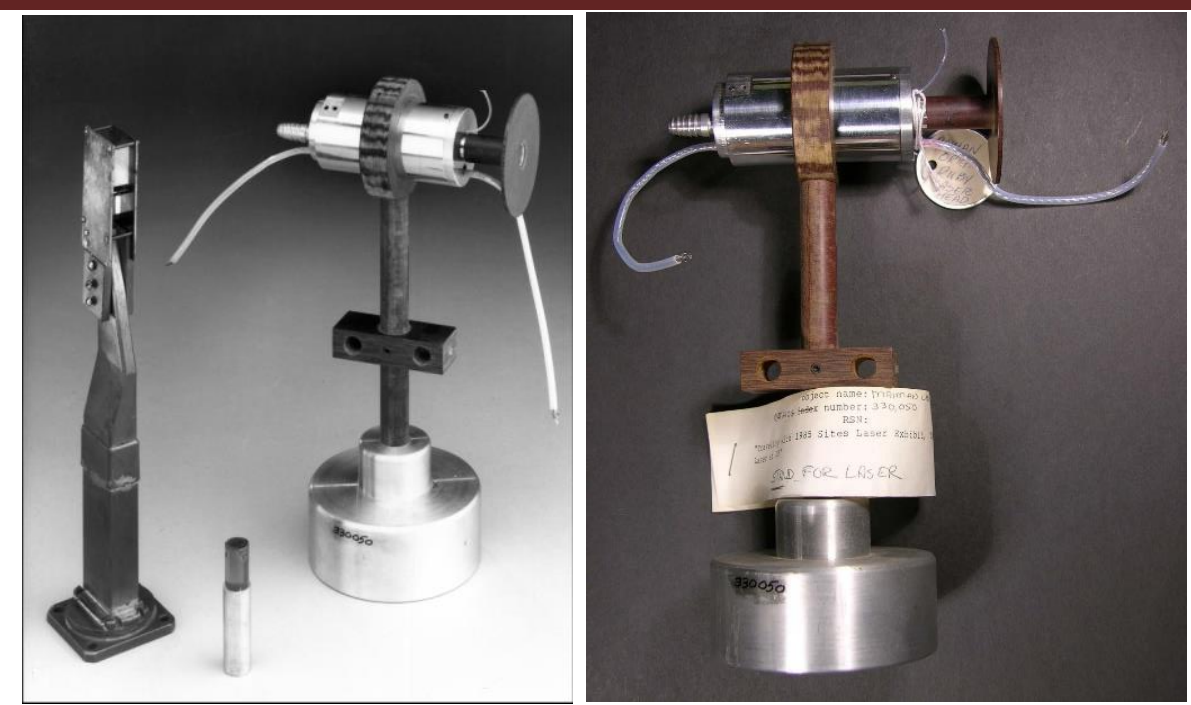

Figure 3. Photographs of one of the possible versions of Theodore Maiman's first ruby laser (National Museum of American History).

By May 1960, Theodore Maiman and Irni D'Haenens at the Hughes Aircraft Company had constructed several small metal cylinders (National Museum of American History). Each of them contained a spiral-shaped xenon flashtube that surrounded a small cylindrical crystal of synthetic ruby. When they lit the flashtube, a flash of light caused the ruby crystal to emit a precisely focused pulse of light - the first emitting laser. Hughes Aircraft donated this and several other Maiman devices to the National Museum of American History Smithsonian Institution in 1970. The crystal inside this device is from the 1961 experiment. Although donation records indicate that this is the first laser, Maiman wrote that he received the first laser as a gift when he left the company in April 1961. During the research, several experimental models were made, which is common practice. Thus, we may never know which device actually generated the first laser beam.

Shortly after Maiman built the first laser, his assistant Irni D'Haenens joked that the laser was "a solution looking for a problem" (Hecht, 2010). As with any good joke, there was an element of truth in this phrase. The laser was not a device invented for specific applications. It was more of a discovery than an invention, using the method for generating coherent light that laser designers expected to find applications in a wide range of fields.

Interesting is the vision of Theodore Maiman himself about the promising areas of application of the laser he created. At the aforementioned press conference on July 7, 1960, Maiman noted the following directions (Shakir \& Patel, 2017):

1. The first true amplification of light;

2.A tool to probe matter for basic research;

3. High-power beams for space communications;

4. Increasing the number of available communication channels;

5. Concentrating light for industry, chemistry and medicine (Shakir \& Patel, 2017). 
It is known that at the press conference, Maiman deliberately tried to avoid discussion about the possible use of lasers as weapons. But after all, he admitted that he could not rule out this option. Maiman's success has inspired other developers and convinced everyone that it was indeed possible to generate laser radiation. This event has filled the laser research community with new energy and new funding. In fact, the concept and design of the Maiman laser was so simple that a few weeks later, its results were replicated by several other researchers, most notably Bell Labs, who demonstrated their version of the ruby laser on August 1, 1960.

Soon after the first demonstration of the laser operation, the search for directions of their practical application began. In 1960-1962, a large number of new laser development companies: Sylvania, Martin Marietta, RCA, Perkin-Elmer, as well as companies that previously produced masers, such as Hughes Aircraft, American Optical, Technical Research Group (TRG), AT\&T, Bell Labs, Raytheon, Quantatron, Korad Inc., etc., were engaged in the production of lasers.

Hecht (Hecht, 2010) briefly describes the first attempts to apply lasers in various industries:

...Bell Labs management saw coherent light as a technology that increase the capacity of the Bell System's backbone telephone network, which in 1960 consisted of chains of microwave relay towers. Plans were already in the works to upgrade the long-distance network to buried millimeter waveguides carrying signals at $60 \mathrm{GHz}$, but Bell had long-term plans to upgrade the telephone system from voice to video, which would require much more bandwidth. Optical frequencies were more than a thousand times higher, so they promised the needed bandwidth.

The Pentagon wanted a new generation of weapons. Deeply unsettled by the 1957 Sputnik launch, the Eisenhower administration created the Advanced Research Projects Agency (ARPA, now DARPA) to invest in high-risk, highpayoff research that other military research agencies had been unwilling to support. Soon after ARPA opened its doors, its first director, Roy Johnson, told Congress he would fund anything that might reduce the threat of nuclear attack, even "death rays." When TRG asked for \$300,000 to try to build a laser using Gould's ideas, ARPA instead gave them \$999,000, hoping for applications in target designation and communications, as well as in missile defense.

Physicians began testing lasers to see if they could treat ailments better than other light sources, particularly in dermatology and ophthalmology, where light was already widely used. The first important laser success was in ruby-laser treatment of detached retinas. Previously, ophthalmologists had focused light from $1000 \mathrm{~W}$ arc lamps into the eye for 1 -s intervals to form scars attaching the retina to the eyeball. The procedure had to be re-engineered to use millisecond laser pulses, but it worked in rabbits, and ophthalmologist Charles J. Campbell treated the first human patient at the Harkness Eye Institute of Columbia University on November 22, 1961. About a week later, Christian Zweng 
performed a similar operation in Palo Alto, California. Both operations were successful.

Physicists focused laser beams to high intensity to study laser-matter interactions. In 1961, Peter Franken focused $3 \mathrm{~J}$ ruby pulses into quartz and generated the $347.2 \mathrm{~nm}$ second harmonic, which appeared as a faint spot on a photo recorded after passing the light through a spectrometer. He and three University of Michigan colleagues called the faint spot an "unambiguous indication of second harmonic," but that didn't stop someone at Physical Review Letters from thinking the spot was a flaw in the photo and editing it out. The Lawrence Livermore National Laboratory wondered about prospects for laserinduced nuclear fusion, and in 1962 formed a group to study the prospects seriously (Hecht, 2010).

First problems. Commercialization of the laser development. "Patent Wars". Manufacturers and companies that tried to apply lasers in different industries had faced the problem of measuring the power of laser radiation. The first ruby lasers produced very powerful pulses - too powerful to be measured with most optical sensors of the time (Mueller, 2010). Researchers placed razor blades in front of the lasers and counted how many blades the laser could drill. This unofficial unit of measurement is called Gillette. The first Maiman's laser produced 1 Gillette pulse. Within a few months, his competitors were assembling a laser with a power capable of burning through 4 Gillette. Today, spot laser welding of stainless steel blades and spring-loaded support rods has become the gold standard for shaving sticks, with laser welding productivity reaches 120,000 single-spot welds per hour (Laser spot welding).

Already in 1961, a new global industrial market - the laser market - has emerged. Initially, the companies produced one-off and small-scale products, and because of this, the cost of the first lasers was relatively high. According to (Hess, 2013), the first commercial laser was manufactured by Raytheon and sold for $\$ 5,850$ at a meeting of the Institute of Radio Engineers in New York in March 1961. This LH-1 pulsed ruby laser (Figure 4) had a housing designed for easy rod and lamp replacement and it operated at room temperature.

The evidence that the first commercial laser was manufactured and sold by Raytheon in 1961 is corroborated in the paper by George J. O'Neill (O'Neill, 1983).

However, Klauminzer (Klauminzer, 1984) claims that a $1 \mathrm{~mW}$ helium-neon laser (He-Ne) was the first to be sold by Spectra-Physics in 1962 for \$ 7,500.

The authors are interested in facts about the development of laser production by its discoverers - Theodore Maiman and Hughes Aircraft Company. 


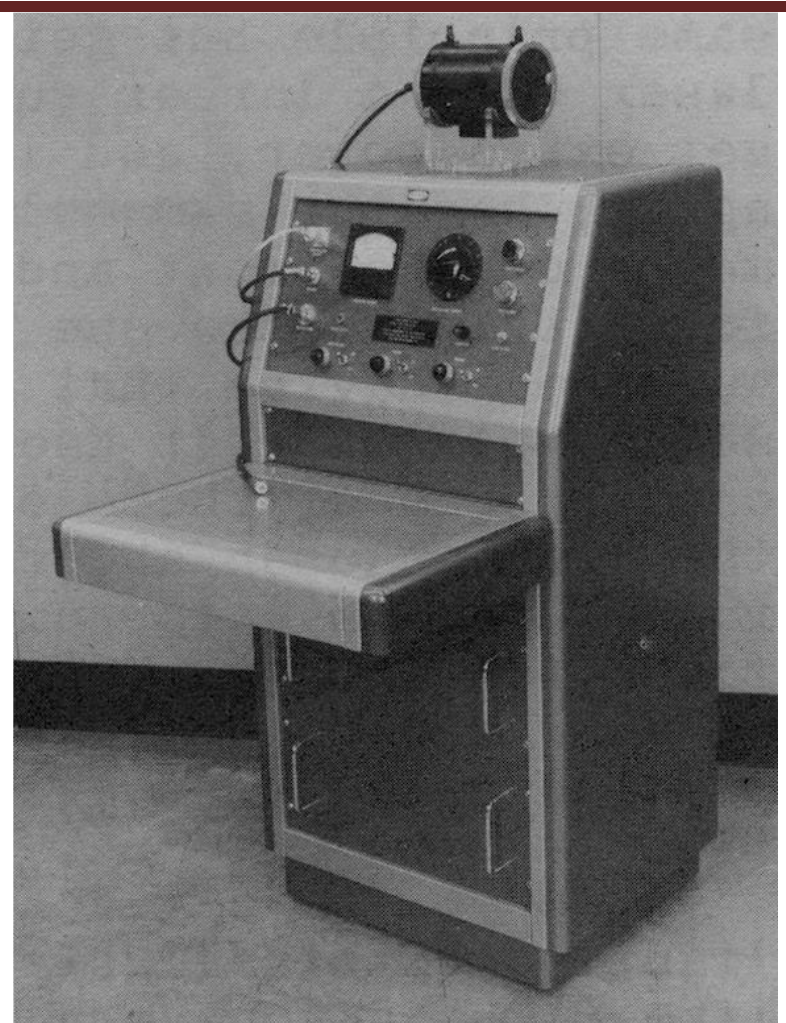

Figure 4. 1961 Raytheon LH-1 pulsed ruby laser system, the first laser model sold commercially (Hess, 2013).

Theodore Maiman was one of the first, initially setting up a laser group at a shortlived company called Quantatron in Santa Monica, California, then taking his laser group to form the core of Korad Inc., also in Santa Monica, with funding from Union Carbide (Hecht, 2010). Korad soon began making ruby lasers based on Maiman's design, as shown in Figure 5.

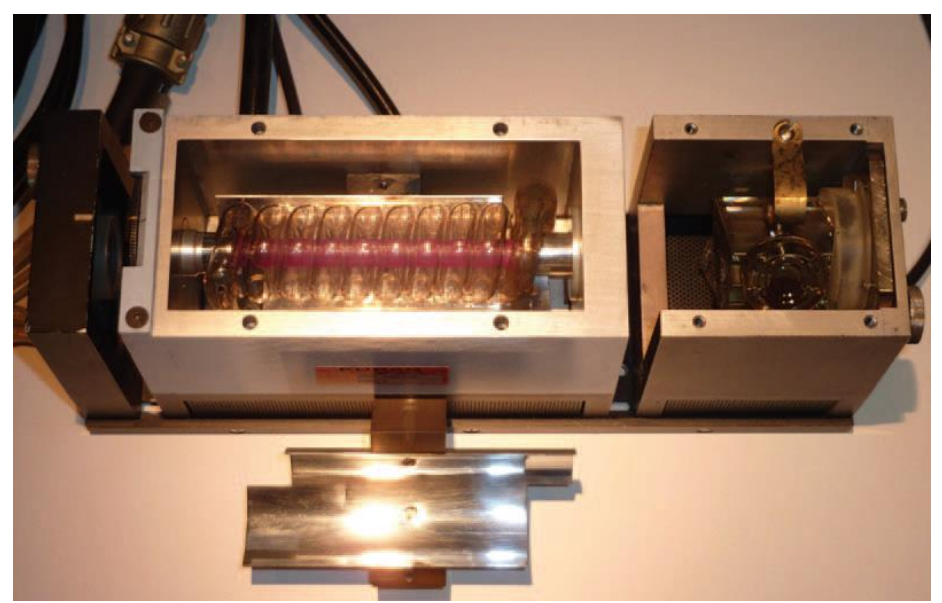

Figure 5. Korad's first commercial ruby laser, serial \#001 of model RL-4KCS. The box at the right is a liquid Q switch. Comparison with that Maiman's original design has been modified byusing a longer flashlamp with with more coils and a longer rod (Hecht, 2010). 
The Hughes Aircraft Company introduced its first commercial laser only in May 1962, despite having built the first laser two years earlier (Anonymus, 1962). This Model 200 pulsed ruby laser was a commercial version of Maiman's first device, but with a longer rod, at the ends of which dielectric mirrors were applied (Figure 6) (Hess, 2013).

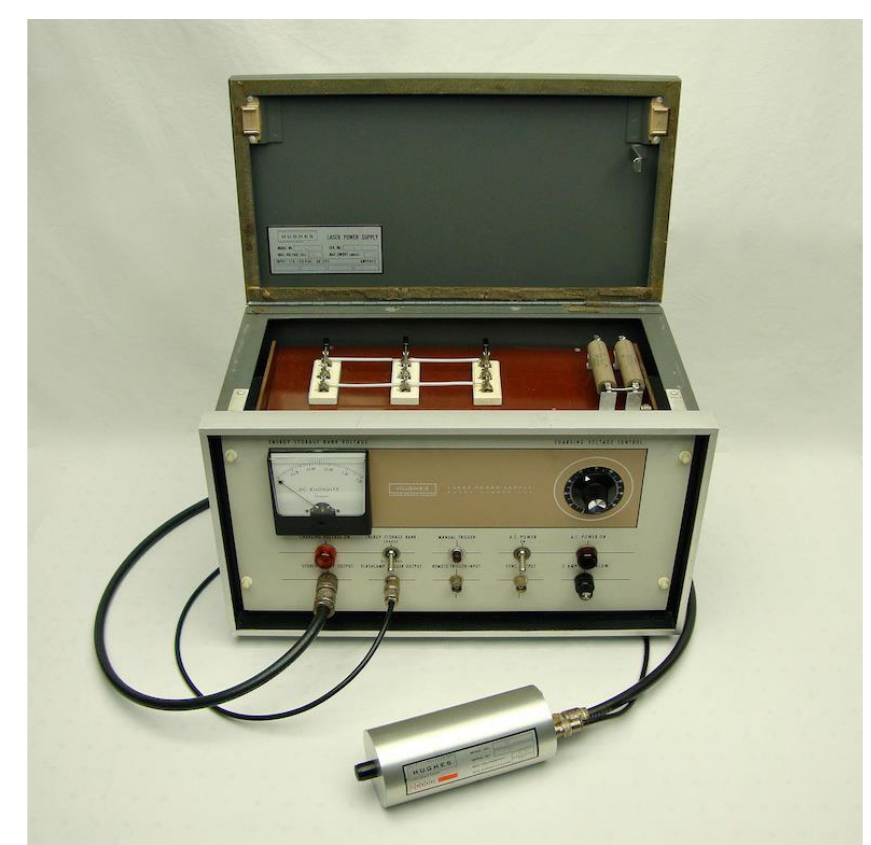

Figure 6. 1962 Hughes Aircraft Company model 200 ruby laser system, fully operational with all original components (Hess, 2013).

In general, in the history of the laser technology development, it is rather difficult to track the primacy of an invention or application in a particular industry. This is due to the fact that manufacturing companies were in no hurry to reveal all the secrets and ideas behind their laser designs. Moreover, a large amount of work was carried out by order of the military departments, which in itself implied a regime of increased secrecy.

In this regard, in the field of the laser technology invention and the use of laser technologies, there have always been a fairly large number of disputes, which have repeatedly escalated into legal proceedings that dragged on for many years.

The most famous is the opposition (or the "Thirty Years Patent War") of Gordon Gould with the United States Patent and Trademark Office for obtaining patents for laser and related technologies. He also fought laser manufacturers in lawsuits to protect the patents he later received. Gordon Gould is the author of the acronym LASER (Light Amplification by Stimulated Emission of Radiation) (Taylor, 2000, pp. 66-70). The thirty-year patent war that it took for Gould to win the rights to his inventions has become known as one of the most important patent battles in history. On October 11, 1977, after nearly 30 years of the "patent war", Gordon Gould obtained a patent for optical pumping, which was later used in about $80 \%$ of lasers. As a result, Gould was granted 48 patents, the most important of which were patents for optical pumping, 
collisional pumping, and application patents (Taylor, 2000, p. 70). However, these technologies covered most of the lasers that were in use at the time. For example, the first operating laser, a ruby one, was optically pumped; the helium-neon laser is pumped by a gas discharge.

Even the inventor of the first ruby laser, Theodore Maiman, was able to obtain a patent for his laser only in 1967, having bought it for $\$ 300$ from the Hughes Aircraft Company (Maiman, 2018, p. 191).

In this regard, the work of Dutta Majumdar and Manna (Dutta Majumdar \& Manna, 2003), in which they tried to systematize and to compare the invention and commercialization of the idea (or application) of different types of lasers, is interesting.

Probably the most heated argument among researchers of the history of lasers is about the fact of the first industrial application of lasers.

Laser Processing of Engineering Materials (Ion, 2005, p. 20) states that the first laser welds were made around 1963, and involved butt and edge joints in $0.25 \mathrm{~mm}$ stainless steel foils, processed with a pulsed ruby laser (Platte and Smith, 1963). Welds were also made between gold connecting leads and aluminium-coated silicon surfaces in microelectronic devices. The laser beam was merely being used to fuse material, albeit very accurately, in a conduction-limited mode. Other reports of research into conduction-limited welding in metals were published (Fairbanks \& Adams, 1964) and applied to joining wires, sheets and circuit boards shortly afterwards (Anderson \& Jackson, 1965; Cohen, Mainwaring, \& Melone, 1969; Conti, 1969), when 0.5 mm was considered to be an upper limit of penetration. The first industrial application appeared around 1965, when a pulsed Nd:YAG laser was used to repair broken connectors inside assembled television tubes (Belforte, 1993, p. 5 as cited in Ion, 2005). Ruby laser welding was used in fabrication of the first Apollo lunar sample return containers in 1969 (Moorhead, 1971). Various laser-based conduction joining techniques have been developed, including soldering and brazing, partly in response to the needs of the microelectronics industries. The first $\mathrm{CNC}$ laser soldering machine, based on a $50 \mathrm{~W}$ $\mathrm{CO}_{2}$ laser was produced commercially in 1976 (Loeffer, 1977).

However, as we have shown earlier, there is a lot of information that is difficult to systematize and subject to thorough analysis in the history of the development and application of laser technology. Perhaps for this reason, some literature sources provide data that does not match the above data and the data of Dutta Majumdar and Manna (Dutta Majumdar and Manna, 2003). For example, George J. O'Neill (O'Neill, 1983) показывает, что в 1962 in a vivid demonstration of the laser's intensity, Professor Louis Smullin, a physicist at the Massachusetts Institute of Technology, used a system developed by the Raytheon Corporation to bounce a powerful ruby laser beam off the moon, 400,000 kilometres (250,000 miles) away. The size of the spot that hit the moon's surface was an estimated 64 kilometres (40 miles) in diameter. By contrast, the beam of a searchlight powerful enough to reach the lunar surface would be spread over thousands of miles. 
Table 1. Commercially available lasers and their industrial applications (Dutta Majumdar \& Manna, 2003).

\begin{tabular}{|c|c|c|c|}
\hline Laser & $\begin{array}{c}\text { Year of } \\
\text { discovery }\end{array}$ & $\begin{array}{c}\text { Commercialised } \\
\text { since }\end{array}$ & Application \\
\hline Ruby & 1960 & 1963 & $\begin{array}{c}\text { Metrology, medical } \\
\text { applications, inorganic } \\
\text { material processing }\end{array}$ \\
\hline Dd-Glass & 1961 & 1968 & $\begin{array}{c}\text { Length and velocity } \\
\text { measurement }\end{array}$ \\
\hline He-Ne & 1962 & 1965 & $\begin{array}{c}\text { Semiconductor } \\
\text { processing, biomedical } \\
\text { applications, welding } \\
\text { Light-pointers, } \\
\text { length/velocity } \\
\text { measurement, } \\
\text { alignment devices }\end{array}$ \\
\hline Carbon dioxide & 1964 & 1966 & $\begin{array}{c}\text { Material processing- } \\
\text { cutting/joining, atomic } \\
\text { fusion }\end{array}$ \\
\hline Nd-YAG & 1964 & 1966 & $\begin{array}{c}\text { Material processing, } \\
\text { joining, analytical } \\
\text { technique }\end{array}$ \\
\hline Argon ion & 1964 & 1966 & $\begin{array}{c}\text { Powerful light, } \\
\text { medical applications }\end{array}$ \\
\hline Dye & 1966 & 1969 & $\begin{array}{c}\text { Pollution detection, } \\
\text { isotope separation }\end{array}$ \\
\hline Copper & 1966 & 1989 & Isotope separation \\
\hline Excimer & 1975 & 1976 & $\begin{array}{c}\text { Medical application, } \\
\text { material processing, } \\
\text { colouring }\end{array}$ \\
\hline
\end{tabular}

For example, the paper by Melinda Rose and Hank Hogan (Rose \& Hogan, 2019) argues that in 1962, a laser was first used to weld watch springs. This could be considered one of the first (if not the first) applications of lasers for metal processing in the industry, but in other sources, this information does not find enough convincing evidence.

Belforte (Belforte, 2010), argues that the first practical, value-added industrial application for the ruby laser invented by Ted Maiman was the drilling of cooling holes in aircraft engine turbine blades. As the operating temperature of these engines increased it was necessary to find a way to cool the blades to prevent thermal damage. 


\section{Laser market. Its formation, development, and modern stage.}

Anyway, the laser market has been rapidly developing since the early 1960s. In 1980 , it was already $\$ 500$ million, according to the authoritative edition of Laser Focus World cited in George J. O'Neill (O'Neill, 1983).

The current market for laser technology is already a completely different amount and sales volume.

Figure 7 (Holton, Overton, Nogee and Belforte, 2016; Holton \& Nogee, 2021) presents data from the authoritative Laser Focus World, which shows how the laser market has changed in recent years.

As seen in Figure 7, laser manufacturers have earned about \$ 16 billion in 2020 .

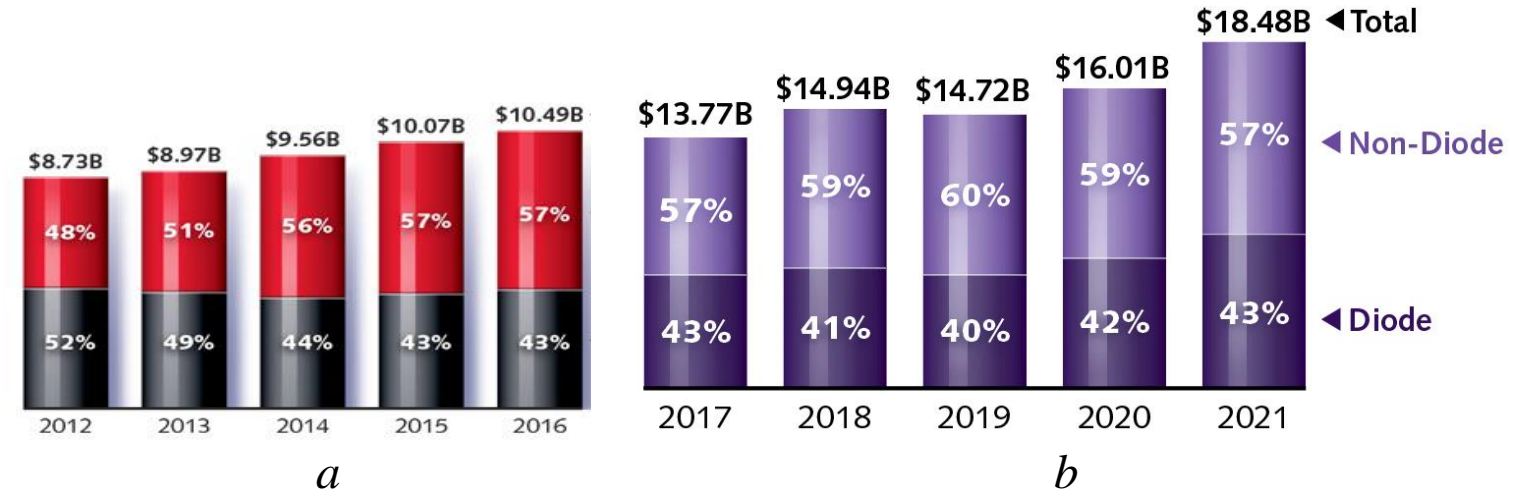

Figure 7. Laser market in 2012-2015 (a) (Holton, Overton, Nogee \& Belforte, 2016) and in 2017-2020 and forecast for 2021 (b) (Holton and Nogee, 2021).

As can be seen from the data in Figure 7, the market for lasers themselves (excluding technological and auxiliary systems, manipulators, and similar equipment) almost doubled and grew practically all the time (except for 2019) constantly and steadily, despite the consequences of global trade conflicts, weak business investments, and COVID-2019, which certainly put pressure on the global economy and increase the risk of long-term stagnation. 2021):

In his publication, Andreas Thoss explains this phenomenon in this way (Thoss,

...2020 was a difficult year for the global economy, but laser markets did surprisingly well. Allen Nogee, President of Laser Markets Research, said that there are at least two different reasons for this resilience in laser markets, as noted in his annual review and forecast of the worldwide laser market. First, lasers are often built into capital goods, and such investments are not made or canceled on short notice. The second reason was the relatively fast recovery of the most important market for lasers and laser systems - China. This logic has been reflected by global and national statistics. The GDP of the U.S. fell 3.6\% in 2020; in Europe, it went down 7.4\%; while in China, it grew 2.3\%. At the same time, the global laser market grew at a remarkable pace of $8 \%$ to $\$ 16$ billion (see figure 3). While the uncertainty of the pandemic remains, Nogee presented an 
optimistic outlook for 2021. On the macro-economic side, he expects aboveaverage growth in the U.S. (3.5\%), Europe (3.6\%), and China (7.9\%). In fact, 2021 could show the highest growth rate in these regions in more than three years. Similarly, the laser market would expand by $10.4 \%$ to $\$ 18$ billion in 2021 (Thoss, 2021).

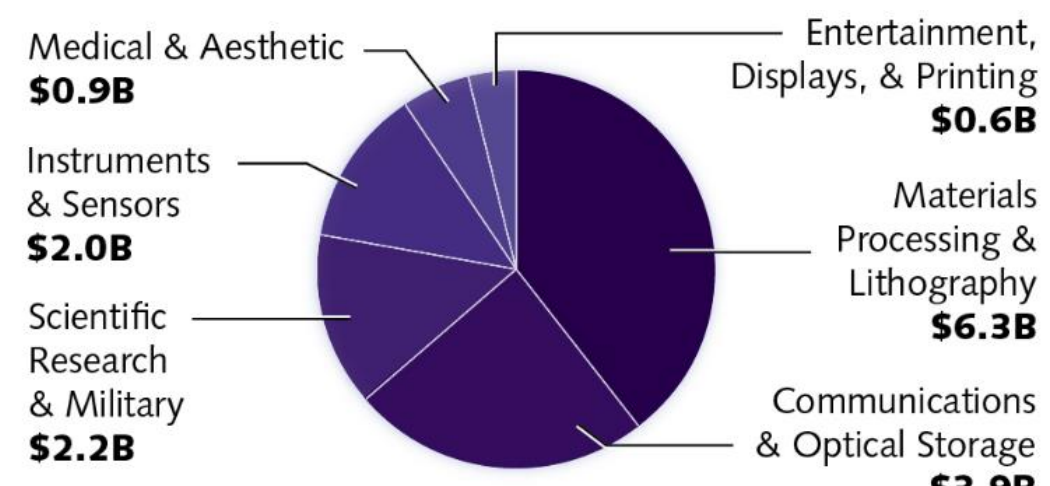

\$3.9B

$a$

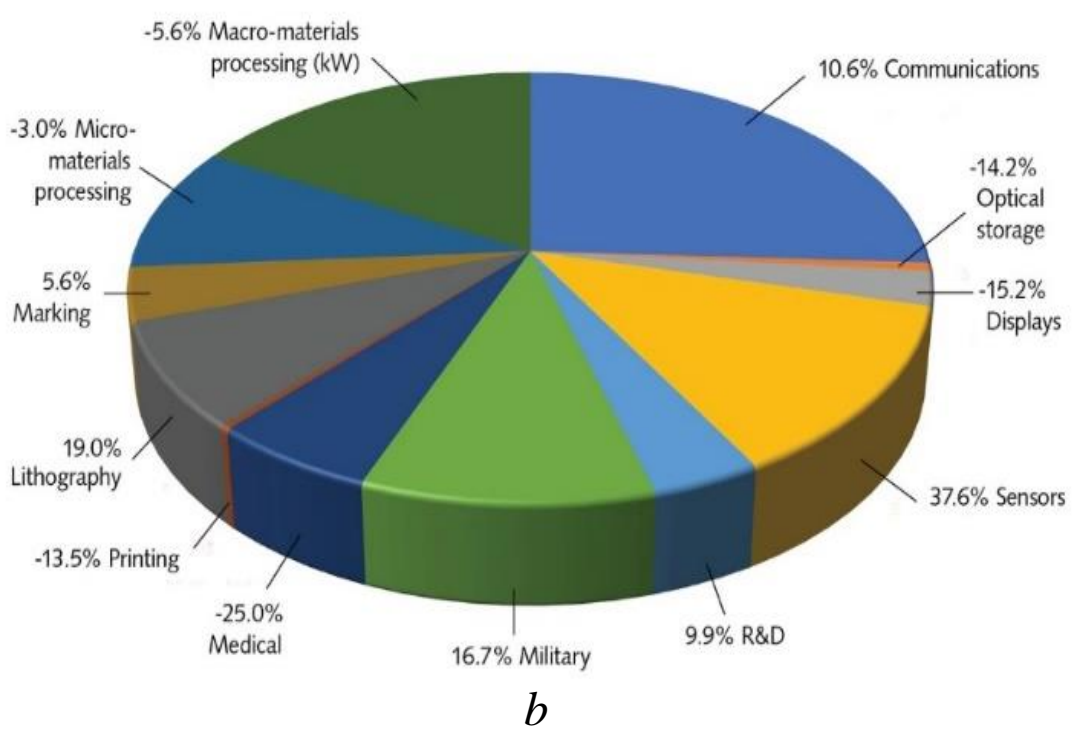

Figure 8. The chart showing the distribution of laser sales in 2020 by the most demanded industries (a) (Holton \& Nogee, 2021) and the percentage distribution of laser sales in 2020 (b) (Thoss, 2021).

Figure 8.a (Holton \& Nogee, 2021) is a chart that shows the distribution of these laser sales by the most demanded industries. Figure 8.b (Thoss, 2021) has a chart that shows the percentage distribution of laser sales in 2020. A "minus" sign for various applications indicates a decline in sales relative to 2019 results.

Historical milestones in the creation and improvement of certain types of lasers and laser technologies for industrial processing of materials.

The charts above show pallid statistics. They in no way convey all the drama of the creation, development, and improvement of the aforementioned laser technology. 
The authors believe that the areas of laser application shown in Figure 8 are worthy of special mention in the context of their invention and improvement of both laser design and technological applications. Limited to the maximum possible volume of publication, the authors have decided to focus on the consideration of little-known historical facts related to the production and operation of lasers for industrial processing of materials.

\section{Mikro-materials processing.}

Laser precision drilling.

In the conditions of the late 1960s and early 1970s, one of the urgent tasks of this area was a radical increase in productivity in the manufacture of a number of miniature products from crystalline materials on an industrial scale. These, in particular, included: jewel bearings and sliding bearings of special precision instruments, which are made of ruby and sapphire; wire-drawing dies made of natural diamond, necessary for drawing thin wire with a diameter of $10 \mu \mathrm{m}$; wire-drawing dies made of artificial diamonds, in which it was necessary to drill and to form shaped holes with a diameter of up to $80-100 \mu \mathrm{m}$ with a tolerance of only a few microns.

In 1965, the first production laser cutting machine was used to drill holes in diamond dies. This machine was made by the Western Electric Engineering Research Center (Bromberg, 1991, p. 202). This event is mentioned in Raytheon News (Anonymus, 1966, January as cited in Earls \& Edwards, 2005, p. 86) (Figure 9).

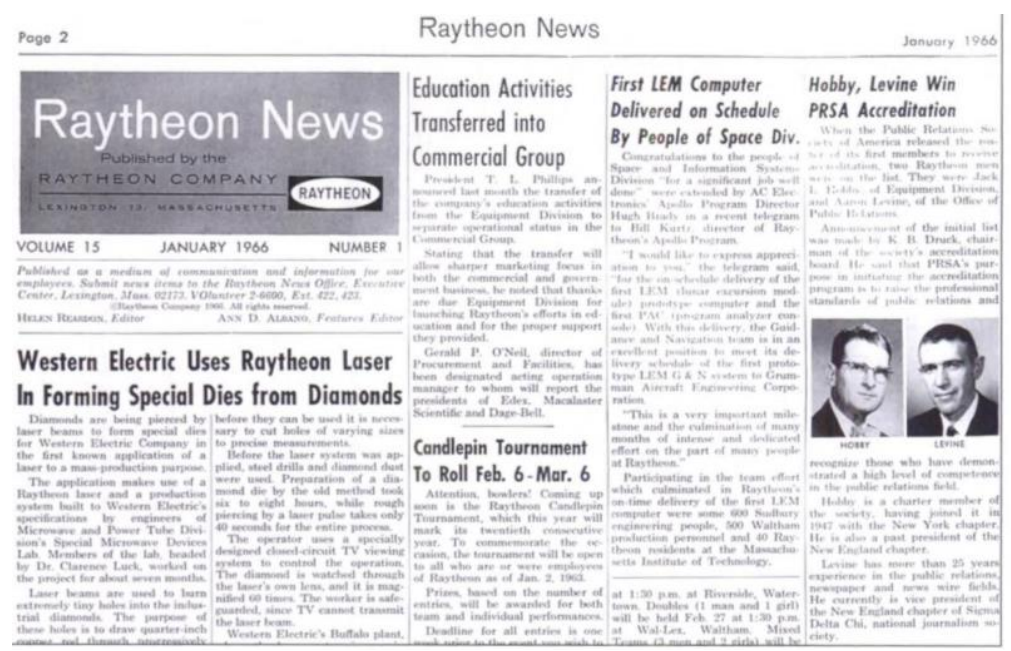

Figure 9. Raytheon News. 15(1) (1966). p. 2 (Earls \& Edwards, 2005, p. 86).

In 1970, by order of the Boeing Corporation, drilling of numerous fans in turbine blades and parts of the "hot zone" of an aircraft gas turbine engine (GTE) was performed using a pulsed ruby laser for the first time at the plant of the American company General Electric, which significantly increased its resource (Vaks, Milen'kij \& Saprykin, 2017, p. 27). By 1974, more than ten advanced Raytheon systems with Nd:YAG-lasers were successfully operating at the production plants of General Electric Ind., the largest manufacturer of aircraft engines for civil and military 
aircrafts and for rocket and space equipment at that time. In 1965, Watch Stones Corp., the Swiss manufacturer of ruby stones for watches, signed a contract with the Institute of Applied Physics at the University of Bern to investigate the possibility of laser drilling of holes in ruby boules, thus opening the "laser era" in Switzerland. At the beginning of 1972, ASUAG (since 1983 - SWATCH Group SA), the leading Swiss watch manufacturer, opened a special laser center for the technological study of the problem. In 1974, the center was transformed into LASAG Corp. with the mission of developing laser equipment and laser drilling technology for watch ruby stones for the Swiss and European watch industry.

\section{Drilling holes in heat-resistant and difficult-to-cut materials.}

By the mid-70s of the last century, with the rapid development of turbojet aviation, the task of improving the resource and increasing the calibration interval for aircraft engines became particularly acute. Dozens of laser systems from Raytheon (SS-500 and SS-550), Lumonics (JK MS-830), and later - Convergent Energy (Gemini with Aurora P50) have already operated at GE Aircraft Engines, Rolls-Royce, and Pratt \& Whitney, etc., for drilling fans in turbine blades of the hot zone and in parts of the combustion chamber of aircraft engines (Vaks, Milen'kij \& Saprykin, 2017, pp. 3132). The number of fans with a diameter of $250 \mu \mathrm{m}$ to $900 \mu \mathrm{m}$ and a depth of $3 \mathrm{~mm}$ to $10 \mathrm{~mm}$ in chrome-nickel heat-resistant and difficult-to-machine alloys reached several hundred per blade and the demand for blades was estimated at hundreds of thousands. With such a mass production, the high speed and productivity of laser drilling superseded the competing processes of electrochemical and electroerosion machining in many factories in a short time. The aerodynamics of the cooling flow of the blade and the complex external and branched internal profile require the arrangement of the fans, according to an individual scheme and at different (including "sharp", up to $15^{\circ}$ ) angles to the surface. Therefore, processing is carried out on special high-speed 5-axis laser machines with precision kinematics. One of the most modern European factories, MTU Aero Engines, is located in Munich and produces modern aircraft engines, assemblies and sets of blades both for the Airbus S.A.S. (for the A-320 and A-380 aircraft family) and other aircraft manufacturers. Blades and parts are machined in three shifts on six LaserTec 80 PowerDrill machines from Deckel-Macho Group (DMG). The machines are equipped with lasers from Lasag and Rofin-Baasel.

The current stage in the development of laser drilling technologies is closely related to progress in the development and production of industrial-grade diodepumped solid-state lasers generating nano- and picosecond pulses at high repetition rates.

\section{Laser mikro-cutting of stents.}

The fine focusability of laser beams is attractive in mikro-materials processing. An outstanding example -and one that revolutionized an industry so much so that it became the process of choice as world demand increased - is laser cutting of stents, 
which started in 1992 (Belforte, 2010). In 1993-1994 a Lumonics low divergence Nd:YAG laser produced limited success cutting stents and was later replaced by a Lasag unit, which became a commonly used laser for this application. Stent cutting, now a major application in the medical devices industry, has been a driver in the introduction of quality, reliable industrial lasers and motion control systems. Flashlamp pumped Nd:YAG lasers were succeeded by diode-pumped units, then disc and fiber lasers, the latter currently the choice for this application. Advanced laser technology in the form of picosecond and femtosecond lasers are being considered for use with the new bioabsorbable stents. Today tens of thousands of stents have been produced worldwide.

\section{Makro-materials processing. \\ Laser welding.}

One of the first laser industrial applications was in welding. The manufacture of mechanical wristwatches has always required maximum precision. It is therefore not surprising that the watch industry relies on laser instruments for almost every node. Haas, a Schramberg-based watchmaker in the German Black Forest region, has pioneered laser welding of wristwatch springs back in 1964 (Quentin, 2017). Welding the watch springs required only low laser power, since the steel springs to be welded were less than one millimeter in size. Shortly thereafter, Haas has begun developing its own laser radiation sources. In 1971, Haas introduced its first proprietary solid-state laser: rod laser on Nd:YAG (neodymium-doped yttrium-aluminum garnet). Beginning in 1992, TRUMPF has begun investing in Haas Laser GmbH to expand its own range of beam sources, which at the time consisted mainly of $\mathrm{CO}_{2}$ lasers. Since then, Haas Laser has grown into TRUMPF's Schramberg site, where solid-state lasers are developed and manufactured.

High-power $\mathrm{CO}_{2}$ lasers with good beam quality and reliable output power were the laser of choice for the joining of sheets of steel that are used in automotive body manufacturing (Belforte, 2010). Although the first laser blank weld was done experimentally for British Leyland in 1981 it was the 1983 application for German auto manufacturer Audi who had need for sheets of metal large enough to be stamped into a limousine underbody that lays rightful claim as the first production laser welded blank. No required sheet sizes were available from German steel mills so Thyssen Steel using a Rofin Sinar $1.5 \mathrm{~kW} \mathrm{CO}$ laser welded two pieces of available size sheet to make the needed size for stamping. Thus was born the laser tailored blank welding business, which today finds laser tailored blank components used by auto manufacturers worldwide. In 1984 Toyota stunned the rest of the global auto industry with the introduction of a laser welded five-piece body side ring for the Camry, which allowed a choice of metal thicknesses to reduce weight and consequently improve fuel economy. As the auto industry's annual demands for tailored blank components increased an increasing number of new blank supplying subcontractors appeared and they asked for and received units with higher power (to $8 \mathrm{~kW}$ ) $\mathrm{CO}_{2}$ lasers. The 
contribution of laser welded blanks to the design and production of lighter weight and more energy efficient vehicles is immense. The ability to mix steel materials and thicknesses has allowed designers to greatly improve body design and to minimize the number of components needed to meet strict crash standards.

\section{Laser cutting.}

The first experiment in laser processing of materials, which later developed into an important industrial process for gas laser cutting of metals, was conducted in May 1967 by Peter Houldcroft, who was then Deputy Scientific Director at The Welding Institute (TWI) in Cambridge, and Arthur Sullivan, who was a laser operator at the Services Electronic Research Laboratory (SERL) in Harlow Houldcroft and Sullivan, using oxygen gas to cut $1 \mathrm{~mm}$ steel sheet with a focused $\mathrm{CO}_{2}$ laser beam. Paul Hilton describes this event in (Hilton, 1997) as follows:

...In early 1967 Houldcroft designed a 'laser cutting nozzle', its important feature being the oxygen pressure chamber which would provide the co-axial reactive assist gas stream in the region of the laser beam focus. This nozzle arrangement can be seen in the photograph in Figure 10, which was taken during the first series of cutting trials made during May 1967. The oxygen gas was kept in the chamber by a flat "pressure window», and the beam focusing lens was positioned above the pressure chamber. The design of the nozzle tip itself, which had a circular orifice $2.5 \mathrm{~mm}$ diameter and used a stand off distance of $1.5 \mathrm{~mm}$, is remarkably close to commercial nozzles in use today. The horizontal laser beam was diverted onto the focusing lens by an aluminised steel mirror. The lens (of focal length about $300 \mathrm{~mm}$ ) and pressure window were made from sodium chloride. It was sometime later that potassium chloride was used. The rectangular block at the top right of the photograph was attached to a rotating handle. This in fact formed the laser shutter and beam stop. The results of this work were soon published in the article (A.B.J. Sullivan, P.T. Houldcroft. (1967). Gas-jet laser cutting. British Welding Journal. pp. 443-445)(Hilton, 1997).

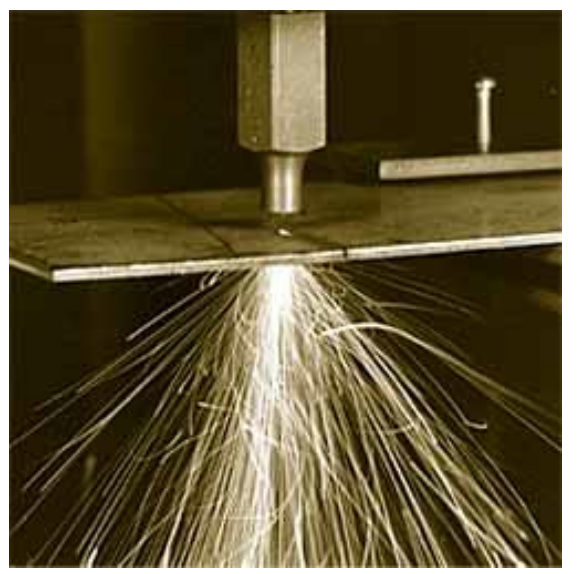

Figure 10. The first oxygen assist gas laser cutting performed in May 1967 (Hilton, 1997). 
The American company Boeing is the first one to integrate laser-cutting on its production lines. In August 1969, three employees from the Boeing Company produced a paper on the $\mathrm{CO}_{2}$ laser cutting off "hard" materials - titanium, Hastelloy and ceramic - using the assist gas technique. They concluded that the laser "could be an effective and economical cutting tool, but a great deal of research and development may be required before such a machine could be put on the production line". In the 1970 's, Boeing patented the multi-beams laser-cutting and was among the pioneering companies cutting titanium with a laser. (Bensoussan, 2016, October 5).

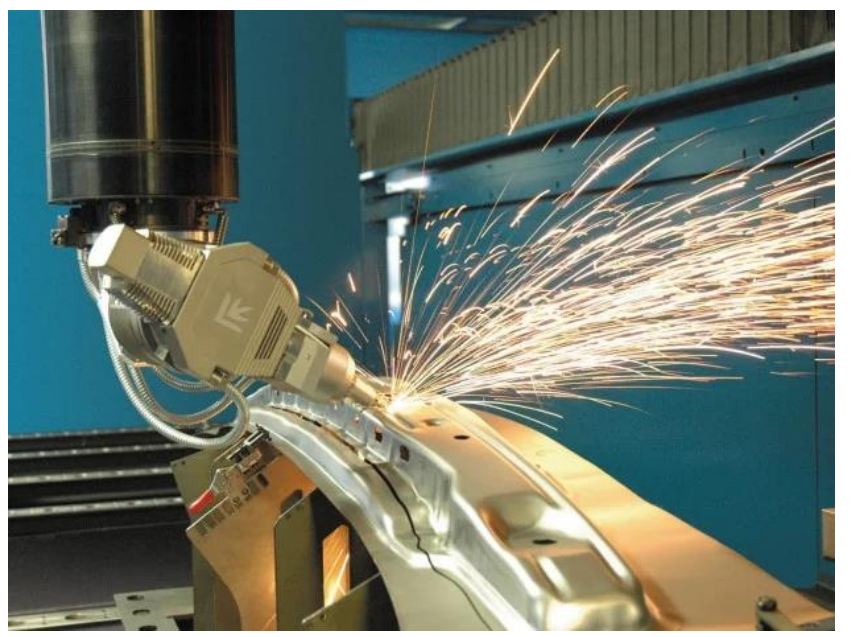

Figure 11. Three-dimensional laser cutting (3D fiber laser machine Rapido Prima Power).

In 1979, the Italian company Prima Industrie has invented the first 3D laser cutting process (History Prima Power). Now, this technology is widely used when cutting cavities and holes with a complex contour in various volumetric parts and structural units using advanced laser cutting machines (Figure 11) (3D fiber laser machine Rapido Prima Power).

One of the major contributions from Japan resulted from developments at Amada in 1985 that led to a "Clean Cut" finish that produced a non-oxidized cut in $3 \mathrm{~mm}$ stainless steel on a system shipped in 1986 (Belforte, 2010, January 1). Subsequently TRUMPF developed inert gas (fusion) cutting with its RF-excited $\mathrm{CO}_{2}$ laser in Germany later in that decade. These processes and others opened the door for highquality metal cutting, without secondary operations, a major industry advance.

\section{The use of laser cutting at the present stage.}

For more than 50 years after the appearance of the first commercial laser cutting machines, technical and technological development in this segment has moved along the path of a slow evolutionary increase in the radiation power of all known types of industrial lasers and, as a result, an equally smooth increase in the speed and productivity of the equipment. The quality, accuracy, service, "friendliness" of the software interface, and the thickness of the workpieces to be processed grew smoothly. 
In the last decade, the development of practical applications of laser cutting has accelerated significantly. This was mainly determined by the industrial development and the appearance of new types of high-power diode-pumped lasers with incomparably higher power density, reliability, service life, and efficiency in the market. One of the signs of the current stage of development is that the undisputed leaders of the 1990s in the field of mass cutting of sheet material $-\mathrm{CO}_{2}$ lasers - have been ubiquitously replaced by powerful fiber-optics and disk lasers in recent years, which have captured more than $70 \%$ of the segment of precision cutting of metals with a thickness up to $20 \mathrm{~mm}$ over the past few years. Another feature of the modern development of laser cutting technologies is associated with the creation of industrial models of pulsed lasers with nano-, pico-, and femtosecond duration of radiation pulses.

\section{Conclusions.}

1. The modern laser technology market continues to develop actively, as evidenced by the steady growth in sales since the early 1980s. This indicates that the demand for laser technology is inextricably linked with the development of high technology production and scientific-technological progress.

2. The progress of industrial laser technology is expressed in reaching the first places in sales of fiber-optics and disk lasers, actively displacing $\mathrm{CO}_{2}$ lasers, as well as in an increase in the share of diode lasers, including for pumping fiber-optics, disk, and Nd:YAG lasers.

3. Recently, the trends in the use of laser technology have changed, in particular, their industrial and medical applications are decreasing, while there is an increase in their use in the fields of sensor production and communication.

4. Due to the emergence and development of laser engineering and technologies, it was possible to bring the aerospace industry (for example, by modernizing the design of turbine blades), high-precision mechanics (for example, drilling jewel bearings, laser-based correction of the accuracy of clockwork), liaison and communication (for example, creation of fiber optic communication) to a qualitatively new level, to create unique cutting technologies (for example, medical stents), and much more.

\section{Funding.}

This research received no external funding.

\section{Conflicts of Interest.}

The authors declare no conflict of interest.

\section{References}

Anderson, J. E., \& Jackson, J. E. (1965). Theory and application of pulsed laser welding. Welding Journal, 44(12), 1018-1026. 
Anonymus. (1962, May 1). Hughes Aircraft adding new line. New York Times, 49.

Anonymus. (1966, January). Western Electric uses Raytheon laser in forming special dies from diamonds. Raytheon News, 15(1), 2.

Belforte, D. (1993). Laser welding: a technology in transition. In Industrial Laser Review Buyers Guide. Nashua: PennWell.

Belforte, D. (2010, January 1). Milestones in industrial laser materials processing. Industrial Laser Solutions. Retrieved from https://www.industriallasers.com/cutting/article/16485102/milestones-in-industrial-laser-materialsprocessing.

Bensoussan, H. (2016, October 5). The history of laser cutting: from MASERs to $\mathrm{CO}_{2}$ laser cutting. Sculpteo. . Retrieved from https://www.sculpteo.com/blog/2016/10/05/the-history-of-laser-cutting-frommasers-to-co2-laser-cutting/.

Bernatskyi, A. V., Berdnikova, O. M., Klochkov, I. M., Sydorets, V. M., \& Chinakhov, D. A. (2019). Laser welding in different spatial positions of T-joints of austenitic steel. IOP Conference Series: Materials Science and Engineering, 582(1), 012048. https://doi.org/10.1088/1757-899X/582/1/012048.

Bernatskyi, A., Sydorets, V., Berdnikova, O., Krivtsun, I., \& Chinakhov, D. (2020). Pore formation during laser welding in different spatial positions. Solid State Phenomena, 303, 47-58. https://doi.org/10.4028/www.scientific.net/SSP.303.47. Bromberg, J, (1991). The Laser in America, 1950-1970. Cambridge: MIT Press.

Choudhury Kaul, S., Sandhu, M. S., \& Alam, Q. (2019). Researching the history of marginalized issues in management research: A proposed interpretive framework. Journal of Management History, 25(2), 237-256. https://doi.org/10.1108/JMH06-2018-0030.

Cohen, M. I., Mainwaring, F. J. \& Melone, T. G. (1969). Laser interconnection of wires. Welding Journal, 48(3), 191-197.

Conti, R. J. (1969). Carbon dioxide laser welding. Welding Journal, 48(10), 800-806.

Dutta Majumdar, J., Manna, I. (2003). Laser processing of materials. Sadhana, 28(34), 495-562. https://doi.org/10.1007/BF02706446.

Earls, A. R., \& Edwards, R. E. (2005). Raytheon Company: The First Sixty Years. Massachusetts: Arcadia Publishing Library Editions.

Fairbanks, R. H., \& Adams, C. M. (1964). Laser beam fusion welding. Welding Journal, 43(3), 97-102.

Hecht, J. (2010). A short history of laser development. Applied optics, 49(25), F99F122. https://doi.org/10.1364/ao.49.000f99.

Hess, R. A. (2013). A survey of lasers at the birth of holography. Journal of Physics: Conference Series, 415(1), 012027. https://doi.org/10.1088/17426596/415/1/012027.

Hilton, P. A. (1997, August 18). Early days of laser cutting. In L. H. J. F. Beckmann (Ed.), Lasers in Material Processing, 3097, (pp. 10-16). Munich: Society of Photo-Optical Instrumentation Engineers https://doi.org/10.1117/12.281076. 
Holton, C., Overton, G., Nogee, A., \& Belforte, D. (2016, February 1). Annual laser market review \& forecast can laser markets trump a global slowdown. Retrieved from https://www.laserfocusworld.com/lasers-sources/article/16546938/annuallaser-market-review-forecast-can-laser-markets-trump-a-global-slowdown.

Holton, C., \& Nogee, A. (2021, February 24). Amid crises and challenges, laser markets stay the course. Retrieved from https://www.laserfocusworld.com/laserssources/article/14196044/covid19-had-a-major-impact-on-global-laser-marketsyet-revenue-remained-generally-healthy.

Ion, J. C. (2005). Evolution of laser material processing. In J. C. Ion, Laser Processing of Engineering Materials. Principles, Procedure and Industrial Application, (pp. 12-40). Oxford: Butterworth-Heinemann. https://doi.org/10.1016/B978075066079-2/50005-2.

Khaskin, V. Yu., Bernatskyi, A. V., Siora, O. V., \& Nikulin, O. T. (2011). Study of influence of conditions of process of laser superficial processing of the loaded steel articles on structure and properties of obtained layers. Metallofizika $i$ Noveishie Tekhnologii, 33(SPEC. ISS.), 561-567.

Klauminzer, G. K. (1984). Twenty years of commercial lasers: a capsule history. Laser Focus/Electro-Optics, 20(12), 54-79.

Loeffer, J. R. (1977). Numerically controlled laser soldering - fast, low cost, no rejects. Assembly Engineering, 20(3), 32-34.

Lukešová, H., Andersen, H. L., Kolínová, M., \& Holst, B. (2019). Is it hop? Identifying hop fibres in a european historical context. Archaeometry, 61(2), 494-505. https://doi.org/10.1111/arcm.12437.

Maiman, T. (1960). Stimulated optical radiation in Ruby. Nature, 186(4736), 493-494. https://doi.org/10.1038/187493a0.

Maiman, T. H. (2018). Hughes Patent Blunders. In: The Laser Inventor. Springer Biographies, (pp 191-200). Cham: Springer. https://doi.org/10.1007/978-3-31961940-8_22.

Markashova, L., Berdnikova, O., Bernatskyi, A., Sydorets, V., \& Bushma, O. (2019). Crack resistance of 14KhGN2MDAFB high-strength steel joints manufactured by laser welding. IOP Conference Series: Earth and Environmental Science, 224(1), 012013. https://doi.org/10.1088/1755-1315/224/1/012013.

Moorhead, A. J. (1971). Laser welding and drilling applications. Welding Journal, 50(2), 97-106.

Mueller, R. (2010, April 6). Going mainstream. Retrieved from https://www.canadianmetalworking.com/canadianmetalworking/news/metalwor king/going-mainstream.

National Museum of American History. (n. d.) Head Piece from Maiman Laser. Retrieved from https://americanhistory.si.edu/collections/search/object/nmah_712855.

O'Neill, G. J. (1983). Laser: the space age tool. The Rotarian, 142(6), 18-21. 
Platte, W. N. \& Smith, J.E (1963). Laser techniques for metals joining. Welding Journal, 42(11), 481-489.

Prima Power. (n. d.). History Prima Power. Retrieved from https://www.primapower.com/our-history/.

Prima Power (n. d.). 3D fiber laser machine Rapido Prima Power. Retrieved from https://www.primapower.com/rapido-3d-laser-machine/.

Quentin, U. (2017, October 8). Time and Light. TRUMPF. Retrieved from https://www.trumpf.com/ru_RU/presse/onlain-zhurnal/time-and-light/.

Rigby, P. (2010, May 01). And then there was light. Retrieved from https://physicsworld.com/a/and-then-there-was-light/.

Rose, M. \& Hogan, H. A. (2019 June). History of the Laser: 1960 - 2019. Retrieved from https://www.photonics.com/Article.aspx?AID=42279.

Shakir, Q. J., \& Patel A. R. (2017). Use of lasers in periodontics. International Journal of Current Research, 9(01), 44806-44809.

Shelyagin, V. D., Krivtsun, I. V., Borisov, Yu. S., Khaskin, V. Yu., Nabok, T. N., Siora, A. V., . . . Nedej, T. N. (2005a). Laser-arc and laser-plasma welding and coating technologies. Avtomaticheskaya Svarka, (8), 49-54.

Shelyagin, V. D., Khaskin, V. Yu., Shitova, L. G., Nabok, T. N., Siora, A. V., Bernatskyi, A. V., \& Chizhskaya, T. G. (2005b). Multi-pass welding of heavy steel sections using laser radiation. Avtomaticheskaya Svarka, (10), 46-49.

Shelyagin, V., Zaitsev, I., Bernatskyi, A., Sydorets, V., Dubko, A., \& Bondarenko, O. (2018). Contactless monitoring of welding processes with computer processing of acoustic emission signals. In Proceeding's 14th International Conference on Advanced Trends in Radioelectronics, Telecommunications and Computer Engineering, TCSET 2018. (pp. 706-710). Lviv: IEEE. https://doi.org/10.1109/TCSET.2018.8336298.

Siora, O. V., \& Bernatskyi, A. V. (2011). Development of basic processing methods of laser welding of joints of dissimilar metals. Metallofizika i Noveishie Tekhnologii, 33(SPEC. ISS.), 569-576.

Storozum, M. J., Zhang, J., Wang, H., Ren, X., Qin, Z., \& Li, L. (2019). Geoarchaeology in China: Historical trends and future prospects. Journal of Archaeological Research, 27(1), 91-129. https://doi.org/10.1007/s10814-0189119-5.

Strelko, O., Pylypchuk, O., Berdnychenko, Yu., Hurinchuk, S., Korobchenko, A., \& Martyian, Y. (2019). Historical milestones of creation of computers technology automated system for passenger transportations management 'express' on the railway transport in the USSR. In Proceeding's 2019 IEEE 2nd Ukraine Conference on Electrical and Computer Engineering, UKRCON 2019, (pp. 12141219). Lviv: IEEE. https://doi.org/10.1109/UKRCON.2019.8879892.

Strelko, O., Pylypchuk, O., Berdnychenko, Yu., Hurinchuk, S., Gamaliia, V., \& Sorochynska, O. (2019). Historical milestones of electrotechnical equipment creation for active experiments in the near-earth space by ukrainian scientists. In 
Proceeding's 2019 IEEE 2nd Ukraine Conference on Electrical and Computer Engineering, UKRCON 2019, (pp. 1229-1234). Lviv: IEEE. https://doi.org/10.1109/UKRCON.2019.8879983.

Sullivan, A. B. J., \& Houldcroft, P. T. (1967). Gas-jet laser cutting. British Welding Journal, 14(8), 443-445.

Taylor, N. (2000). LASER: The inventor, the Nobel laureate, and the thirty-year patent war. New York: Simon \& Schuster.

The Welding Institute. (n. d.). Laser spot welding. Retrieved from https://www.twiglobal.com/media-and-events/insights/laser-spot-welding.

Thoss, A. (2021, May 20). Global laser markets in the time of COVID-19. Retrieved from https://www.laserfocusworld.com/photonics-business/article/14200786/ global-laser-markets-in-the-time-of-covid19.

Vaks, E., Milen'kij, M., \& Saprykin, L. (2017). Praktika precizionnoj lazernoj obrabotki [The practice of precision laser processing]. Moscow: Technosphere.

Van Lent, W., \& Durepos, G. (2019). Nurturing the historic turn: "history as theory" versus "history as method". Journal of Management History, 25(4), 429-443. https://doi.org/10.1108/JMH-03-2019-0017.

Wikipedia. (n. d.). Theodore Maiman. Retrieved from https://en.wikipedia.org/wiki/Theodore_Maiman

Zhang, B., \& Liu, Y. (2019). An overview on the studies of the history of machinery in China. In: Zhang B., Ceccarelli M. (Eds.), Explorations in the History and Heritage of Machines and Mechanisms. History of Mechanism and Machine Science, 37. (pp. 64-73). Cham: Springer. https://doi.org/10.1007/978-3-03003538-9_6

\section{Артемій Бернацький}

Інститут електрозварювання ім. С. О. Патона Національної академії наук України, Україна

\section{Владислав Хаскін}

Гуандунський інститут зварювання (Китайсько-український інститут зварювання ім. С. О. Патона), Китай

\section{Історія створення лазерів і аналіз впливу їх застосування при обробці матеріалів на розвиток певних галузей промисловості}

Анотація. Стаття присвячена аналізу історії створення лазера, як одного з найбільш значущих технічних винаходів 20 століття. Ця стаття присвячена встановленню зв'язку між періодизацією етапів винаходу та впровадження окремих видів лазерів, з їх впливом на створення окремих видів техніки $i$ промислових технологій обробки матеріалів, розвитком певних галузей економіки та науково-технічного прогресу в цілому. При підготовиі статті використовувалися загальноприйняті методи, які широко використовуються 
при підготовці історичних дослідницьких робіт: історичний метод, - для вивчення та інтерпретації текстів першоджерел $і$ пошуку інших доказів, які використовуються для дослідження, а також викладу історичних подій пов'язаних з розвитком лазерної техніки; історико-генетичний метод, - для вивчення генезису конкретних історичних явищ $i$ аналізу причинності змін $y$ розвитку лазерної техніки; історико-критичний метод, для відображення причинно-наслідкових зв'язків, відтворення подій, щзо вплинули на розвиток лазерної техніки; метод історичної періодизації. Різноманіття різних можливих варіантів застосування лазерів позбавило змоги розмістити всі зібрані матеріали в рамках однієї статті $і$ тому автори вирішили зупинитися на фактах, які на їх думку є найбільш цікавими, значущуими, слабовивченими $і$ маловідомими. У статті розглянуті етапи: винаходу першого лазера; створення периих комерційних лазерів; розробки периих застосувань лазерів в промислових технологіях обробки матеріалів. Окремо приділено увагу «патентним війнам», які супроводжували різні етапи створення лазерів. Проведено порівняльний аналіз розвитку ринку лазерної техніки від етапу створення до сучасності. Показано, щуо сучасний ринок лазерної техніки продовжує активно розвиватися, про щзо говорить стабільне зростання продажів лазерів, щзо триває останні 10 років. Це свідчить про те, щзо попит на лазерну техніку нерозривно пов'язаний з розвитком наукоємного виробництва $i$ науково-технічним прогресом. Проведений аналіз показав, щзо в останній час змінилися тендениії використання лазерної техніки, зокрема відбувається скорочення їх промислового $i$ медичного застосування, при цуьому спостерігається зростання їх застосування в областях виробництва сенсорів $i$ комунікації.

Ключові слова: лазер; історія лазерів; Теодор Майман; Національний Музей Американської Історії; ринок лазерів; застосування лазерів

\section{Артемий Бернацкий}

Институт электросварки им. Е. О. Патона Национальной академии наук Украины, Украина

\section{Владислав Хаскин}

Гуандунский институт сварки (Китайско-украинский институт сварки им. Е. О. Патона), Китай

\section{История создания лазеров и анализ влияния их применения при обработке материалов на развитие определенных отраслей промышленности}

Аннотация. Статья посвящена анализу истории создания лазера, как одного из величайших технических изобретений 20 века. Настоящая статья посвящена установлению связи между периодизащчей этапов создания $и$ 
внедрения отдельных видов лазеров, с их влиянием на изобретение отдельных видов техники и промылиленных технологий обработки материалов, развитием определенных отраслей экономики и научно-технического прогресса в целом. При подготовке статьи применялись общепринятые методы, иироко используемые при подготовке исторических исследовательских работ: исторический метод, - для изучения и интерпретации текстов первоисточников и поиска иных доказательств, используемых для исследования, а также изложения исторических событий связанных с развитием лазерной техники; историко-генетический метод, - для изучения генезиса конкретных исторических явлений и анализ причинности изменений в развитии лазерной техники; историко-критический метод, для отображсения причинноследственных связей, воссоздания событий повлиявиих на развитие лазерной техники; метод исторической периодизачии. Многообразие различных возможных вариантов применения лазеров не позволило разместить все собранные материаль в рамках одной статьи и поэтому авторы решили остановиться на фактах, которые по их мнению являются наиболее интересныли, значимыли, слабоизученными и малоизвестными. $B$ статье рассмотрень этапь: изобретения первого лазера; создания первых коммерческих лазеров; разработки первых применений лазеров в промыиленных технологиях обработки материалов. Отдельно уделено внимание «патентным войнам», которые сопровождали разные этапы создания лазеров. Проведен сравнительный анализ развития рынка лазерной техники от этапа создания до современности. Показано, что современный рынок лазерной техники продолжает активно развиваться, о чем говорит продолжающиийя стабильный рост продаж лазеров за последние 10 лет. Это свидетельствует о том, что спрос на лазерную технику неразрывно связан с развитием наукоемкого производства и научно-техническим прогрессом. Проведенный анализ показал, что в последнее время изменились тенденции использования лазерной техники, в частности происходит сокращение их промышленного $и$ медицинского применения, при этом наблюдается рост их применения в областях производства сенсоров и коммуникации.

Ключевые слова: лазер; история лазеров; Теодор Майман; Наџиональный Музей Американской Истории; рынок лазеров; применения лазеров

Received 13.03.2021

Received in revised form 17.05.2021

Accepted 22.05.2021 